\title{
CAREER DEVELOPMENT, PLANNING AND MANAGEMENT FROM THE ORGANISATIONAL PERSPECTIVE
}

This chapter focuses on career development, planning and management from the organisational perspective. It takes the position that there are two parties, the individual and the organisation, that participate in these career developmental processes and benefit from them. In contrast to the vocational psychological perspective (see Chapter 5), which takes more of an individual-level approach, this chapter considers the individual from the workplace organisation's point-of-view. The chapter begins by defining and contextualising the notion of career. It then differentiates among career development, planning and management, and proceeds to examine the many organisational processes and practices that combine to influence an individual's career pathway during his or her working life.

\section{THE NOTION OF CAREER}

A career is not simply a job, but rather a lifelong endeavour comprising behaviours, attitudes and feelings in a developmental process driven by people's work and life goals and moderated by the organisations they work in (Baruch, 2004; Greenhaus, Callanan, \& Godshalk, 2000). Thus, the development of a career is a long-term and complex process influenced by those psychological, sociological, educational, physical, economic, environmental and fortuitous factors that converge to shape it during a person's lifetime (McDaniels \& Gysbers, 1992). Traditionally, from the organisational perspective, career development for adults was seen clearly as an organisational responsibility, whereby organisations established policies and processes to implement and foster career development, primarily to the advantage of the organisation, and only secondly to the benefit the individual. More recently, increased globalisation of the business world and rapid technological advances have increased competition and forced large scale restructuring on organisations, such as the replacement of full-time staff with temporary and part-time employees, and a movement to flatter organisational structures (Fieldman \& Ng, 2007). As a consequence of these organisational changes, many employers are no longer able, or willing, to offer employees traditional support and advancement opportunities that might encourage them to commit to, and remain within an organisation for long periods, or even a lifetime (Gratton \& Hope Hailey, 1999). Individuals themselves may also be reorientating their values and goals and be less prepared to travel these traditional paths (Arthur \& Rousseau, 1996). In this climate, employees, on the one hand, have been given, and to some extent have sought, increased responsibility for their own career development (Baruch, 2004); whereas on the other hand, employers have become rather more pragmatic and organisationally focused with their developmental activities (Winterton \& Winterton, 1999).

\section{CAREER PLANNING, CAREER MANAGEMENT AND CAREER DEVELOPMENT}

Career planning, career management and career development are overlapping terms sometimes used interchangeably in the research literature, by practitioners, and by workers and employers themselves. Both individuals and organisations engage in all three processes, although they have somewhat different motivations, practices and expected outcomes. Here we briefly outline, from the organisational perspective, individual career planning, management and development, in which, nevertheless, it will be seen, the organisation plays a major role. The following section focuses on organisational career planning, management and development which, for convenience, we subsume under the heading of organisational career management (Baruch \& Peiperl, 2000).

Career planning for the individual is an ongoing, iterative process that involves developing an understanding of one's self and one's goals, as well as becoming aware of the educational and labour market opportunities and impediments to one's expected fit in the world of work. Ideally, it involves informed choices about occupational and life directions (Hall \& Associates, 1986; Leibowitz, Farren, \& Kaye, 1986). 
Career management involves those personal competencies and organisational influences and structures that allow and drive individuals to acquire the requisite skills, knowledge and attitudes to achieve their own career and personal goals and to meet the demands of their work environment. It is an ongoing process of refining, implementing and monitoring the plans made and the steps undertaken by the individual and his or her workplace (Hall \& Associates, 1986; Leibowitz et al., 1986). There are two distinct types of career management strategies (Sturgess, Guest, Conway, \& Mackenzie Davey, 2002). The first targets skills and strategies that enhance a career within the individual's present organisation, such as in-house training and fostering contacts with influential people. The second targets skills and strategies that enhance a career generally, such as obtaining higher level qualifications and forming contacts through trade and professional associations. The strategy emphasised by the individual depends on complex factors, such as commitment to, and satisfaction with, the organisation, and will be influenced by the type and level of career management and development assistance offered by the organisation (DeVos, Buyens, \& Schalk, 2003).

Career development has three broad phases (Herr, Cramer, \& Niles, 2004). First, schools and postsecondary colleges and universities provide young people with workplace relevant skills, knowledge and attitudes that prepare them for taking their place in the world of work. Second, young people acquire the competencies to bridge the gap between attending formal educational institutions and settling into a life that involves full-time employment. Third, development occurs within the workplace itself, when individuals are orientated and developed to the requirements of their employers. This phase largely has an employer focus, meaning that much of this development is aimed at organizational efficiency (Hall, 2003), although career development in this context can and does benefit individual employees. Employees are socialized to the culture and demands of their jobs, and they receive ongoing training and guidance on how to adapt to the changes that will occur within themselves and to the organization.

\section{THE FUNCTIONS OF ORGANISATIONAL CAREER MANAGEMENT}

Organisational career management practices, some of which are also discussed in Chapter 8, serve many organisational functions. The primary goal is to ensure that the organisation has sufficient numbers of appropriately skilled and motivated staff to meet its current and anticipated future needs (Morrison \& Hock, 1986). To this end, organisations engage in formal and informal skills audits to determine the level and type of skills available to them and to match these with the skills required. Skills audits drive a diverse range of planning and training activities, such as succession planning, recruitment and retrenchment. Organisations have a vested interest in improving employee productivity, which is linked directly to the organisation's success and survival, and is accomplished, in part, by in-house and external development activities, such as skills training, job-rotation and work redesign. Organisations also wish to retain critically-skilled and productive employees, and employ practices, such as developing and promulgating mission statements and goals and linking individual career pathways to these goals, so that incumbents develop a commitment to the organisation and see a future for themselves within the organisation. Finally, organisations often make commitments to help resolve personal, family and other non-work intrusions, and to create workplaces that are free of conflict, poor supervision, and health and well-being hazards. Some organisations understand that employees come to work with other important roles and challenges that demand their attention, and that in the work place, productivity and commitment can be undermined by poor work practices and procedures, and by ignoring the external demands placed on their employees (Gottfredson, 2005).

Such approaches to organisational career management practices reflect the notion that an organisation's workforce is its most important asset and it should be given opportunities and assistance to grow and develop. However, not all organisations work from this assumption; rather, some tailor their career development and management strategies and practices to fit with a different management perspective. Two perspectives, depreciation and conservation (Yeatts, Folts, \& Knapp, 2000), have been identified as influencing the types and levels of training and development an organisation invests in its workforce. The depreciation perspective assumes that "an individual's value to an organisation peaks early in a career, levels off at mid-career, and steadily declines until retirement”, whereas the conservation perspective "views employees of all ages as renewable assets that will yield a high rate of return over long periods of time, if they are adequately educated, trained, and managed” (Hedge, Borman, \& Bourne, 2006; p. 342). Organisations that have adopted the depreciation model would, for example, view older workers as less productive, less able to benefit from development activities, and more likely to be offered inducements to leave the organisation, whereas organisations with a conservation approach would be more likely to assist all individuals, irrespective of age, to realise their potential. 
Organisational career management practices are also influenced by the type of organisation, its strategic goals, and the environment in which it operates (London, 2002). Some organisations, for example, those that are heavily multinational, might require employees who are flexible, self-managing and who value diversity, and will structure selection and development activities to generate a workforce that reflects these characteristics. These development activities are likely to differ from those of manufacturing firms that may require more stable, technically skilled employees. Similarly, the external labour market may dictate the types and importance of training and development activities implemented. Organisations will take a different perspective depending on the mix of skills needed and the mix of skills available from the existing labour pool.

The human resource management (HRM) literature has stressed that the career development and management of employees needs to enhance the competitive advantage of the organisation, and is, thus, not merely about developing individuals; rather, "it is about developing and maintaining the full management and organizational capability of an organization” (Suutari, 2002, p. 219). HRM functions are powerful tools within organisations used to achieve the goals of the organisation; goals achieved often at the expense of the individual's own aspirations and needs. The term, human resource management, carries with it the connotation of possession and control, and reflects an organisational perspective that human capital, while considered valuable and important, needs to be marshalled and developed for the ends of the organisation (Herriot, 1992). To achieve these ends, organisational management has been urged to ensure that career development in organisations is linked to the business plan, focused on organisational rather than individual effectiveness, and gives due regard to internal and external environmental demands (McClelland, 1994; Winterton \& Winterton, 1999).

Competency-based models of development are increasingly the model of choice for implementing strategies and practices that achieve the organisation's goals. A competency is "the ability to perform particular tasks and duties to the standard of performance expected in the workplace... [They] cover all aspects of workplace performance and involve performing individual tasks; managing a range of different tasks; responding to contingencies or breakdowns; and, dealing with the responsibilities of the workplace, including working with others" (National Training Information Service, 2008). Competencies can be considered as generic (e.g., applicable across organisations) or contextualised (e.g., specific to an organisation or role within an organisation). Once competencies have been identified and defined, they form the basis for many of the HRM activities within an organisation and are considered the driving force behind training and development programs (Brake, 1997).

Several researchers have attempted to catalogue and classify organisational career management practices (e.g., Baruch, 1996; Gutteridge, Leibowitz, \& Shore, 1993). Some practices, and/or their intent, have been viewed as primarily organisationally focused (e.g., performance appraisal, transfers), others have been categorised as primarily directed at the career needs of individuals (e.g., financial counselling, stress management), while some are seen as meeting the needs of both parties (e.g., mentoring programs, career counselling by HRM staff; Bernes \& Magnussen, 1996). Organisational career management practices can also meet organisational and individual goals over and above those directly related to career progress and organisational efficiency, such as reducing the tension that might exist between "individual worker's needs, goals and aspirations” and the "organisation's need and requirements” (Herr et al., 2004, p. 497).

\section{THEORIES OF ORGANISATIONAL CAREER DEVELOPMENT}

Despite the agreed-upon significance of organisational career management and development (Arnold \& Cohen, 2007; Baruch, 2002; Hall, 2002), the theoretical underpinning of the area is weak (Arnold \& Cohen, 2007; Arthur, Hall, \& Lawrence, 1989). Most of the theoretical and empirical work related to adult careers has taken an individual rather than an organisational, or joint, perspective (Baruch, 2002). As late as 2000, Baruch and Peiperl were able to conclude that, "the organizational aspect in career theory still lacks a comprehensive framework... There is not yet an accepted theoretical model of [organisational] career processes - let alone any empirical tests of such a model” (p. 347). Nor are there well developed organisational career systems that parallel organisational HRM systems (Bagdadli, 2007). Organisational career systems are "the policies, priorities, and actions that organisations use to manage the flow of [employees] into, through, and out the organization over time" (Sonnenfeld \& Peiperl, 1988, p. 558), and include entry, development and exit strategies for employees. Here we shall note some models of career development before outlining some widely used theories of career development.

Apart from the attempts to devise normative models to classify organisational career management practices, which were identified above (and see Baruch, 2002; Baruch \& Peiperl, 2000), some organisational career theorists have proposed career development models based on the dimensions of 
the organisations themselves. Sonnenfeld and Peiperl (1988), for example, proposed two organisational dimensions, the first of which was employee supply flow. This refers to how open or closed an organisation is to recruiting staff from outside the organisation. Some organisations will limit much of their recruitment to entry-level personnel and rely on internal promotions and transfers to fill vacancies at higher levels, whereas other organizations have a very open staffing policy that allows both internal and external competition for most or all jobs in the organisation. The second dimension was assignment flow. This refers to the criteria used for employee development and promotion. Some organisations favour an approach that rewards individual performance, whereas others approach assignment allocation and promotion along other dimensions, such as seniority. Each of the four different types of organisations that can be generated from these two axes (i.e., high/low supply flow $x$ high/low assignment flow) requires a different HRM policy on career management as each has different development demands resulting from their respective staffing policy. For example, an organisation that is open to external recruitment at all levels and allocates assignments based on individual competence requires a different career development approach to an organisation that relies on recruiting early career employees and then developing and promoting them within the organisation. However, while this model does take an organisational perspective, its major weakness is that it gives little consideration to the individual employee in the situation.

Ideally, a model of career development and management should consider the career from both the individual and the organisational perspective. Such a model was proposed very early on by Schein (1971). He described the organisation in terms of vertical (possible upward and downward mobility), radial (possible mobility to and from the inner circle of influence), and circumferential dimensions (possible mobility across the organisation; e.g., from one department to another). For Schein, the important dimensions for employees were their socially constructed selves, which developed and changed during the course of a career as they traversed these three organisational dimensions. Even so, Schein based his model on a narrow perception of the organisation as being static and hierarchical, which is seldom the case today, and viewed the socialisation process very much one way from the organisation to the individual.

More recently, Herriot and Pemberton (1996) proposed a model where the employee's career identity drives their understanding of their needs, values, and capabilities. These insights then allow the employee to identify what they want from an occupation/organisation and identify what they have and are prepared to offer, both of which, in combination, determine what occupational roles they will seek or avoid. For their part, organisations operate in a commercial context. This context determines the structure and strategic policies of the organisation that, in turn, determine what it needs and wants from its employees and what it can offer in return. The model assumes an ongoing negotiation between the employee and the organisation. During this negotiation, the individual's needs are matched with the organisation, and the organisation's needs are matched with the employee's offers. At some points in the ongoing negotiation the individual will have a stronger negotiating position (e.g., when the individual's skills are in short supply), and at other times, the organisation will hold the upper hand (e.g., when the employee's skills are in oversupply). The strength of this model is that it does not view career development merely as a series of career decisions; rather it attempts to explain career development as an ongoing, interactive process between the individual and the individual's everchanging organisational context. However, it does place considerable emphasis on the individual's negotiating powers and has little explanatory power for employees not in an organisational context (e.g., the self-employed) and those in relatively weak organisational positions (e.g., semi- and unskilled employees). This model has many similarities with the psychological contract perspective, which is reviewed next.

\section{The Psychological Contract}

Employee expectations about organisational obligations do not always match with organisational expectations, and vice versa. Mutual understandings and misunderstandings about obligations are conceptualised by the psychological contract (Argyris, 1960; Levinson, Price, Munden, Mandl, \& Solley, 1962), which is a voluntary social exchange relationship embedded in both formal and/or informal contracts between an organisation and the employee (Robinson \& Morrison, 1995). The psychological contract affects the attitudes, behaviours and motivations of both parties. It is also "likely to reflect [the] promises, expectations and experiences regarding [the management of] careers" (Sturges, Conway, Guest, \& Liefooghe, 2005, p. 822), which, in turn, affects the steps that individuals and organisations take to foster career development. Two main types of contracts have been identified, namely transactional and relational (Rousseau 1990, 1995). Transactional psychological contracts are short-term focused, imply little close involvement between the parties, and revolve around 
compensation and benefits. Employees commit to hours and productivity in return for favourable remuneration and other personal benefits. Relational psychological contracts are more socio-emotional in nature. They are based on exchanges of loyalty and trust, and commit both parties to longer term arrangements during which obligations around training, personal and career development, and guarantees of job security come to the fore.

Using a representative sample from the United Kingdom labour market, Herriot, Manning, and Kidd (1997) examined the mutual, perceived expectations implicit in the psychological contract between organisational representatives and employees. These authors found few differences in perceptions of the most frequently identified obligations relating to hours and quality of work and honesty. However, they found significant differences between employee and organisational representatives regarding both organisational and employee obligations. Organisational representatives ranked recognising employees' contributions, supporting employees and providing fair and consistent benefits more important than employees, whereas employees ranked a safe and congenial work place, security and pay as being more important. For employee obligations, organisational representatives rated appropriate dress and behaviour and respecting the organisation's property higher, whereas employees rated loyalty to the organisation and putting its interests first more important than employers. Herriot et al. concluded that employees more often stressed the transactional factors of basic pay and conditions factors, whereas employers emphasised more relational factors.

Perceived differences between employees and organisations about mutual obligations place the psychological contract under strain as they breach the reciprocity principle (Rousseau \& Parks, 1993). Reciprocity is the tacit agreement between the two parties that carrying out their side of the bargain is contingent on the other side meeting their obligations. Contract breaches or violations reduce employees' trust, lower their job satisfaction, prompt them to reconsider their obligations and commitment to the organisation (Robinson \& Rousseau, 1994), and in extreme cases may tempt them to seek revenge or retaliation. As a consequence, the efficiency and profitability of the organisation may be lowered and the individual's work and career development disrupted, sometimes severely. Psychological contract breaches have been shown to have negative effects on trust (Robinson, 1996), job satisfaction (Tekleab, Takeuchi, \& Taylor, 2005), organizational commitment (Guzzo, Noonan, \& Elron, 1994), turnover (Turnley \& Feldman, 1999), job performance and citizenship behaviours (Turnley, Bolino, Lester, \& Bloodgood, 2003).

\section{Person-Organisational Fit}

Psychological contract violations also have an effect on the fit between the person and the organisation (Bocchino, Hartman, \& Foley, 2003). Person-organisation fit is "the compatibility between people and organizations that occurs when: (a) at least one entity provides what the other needs, or (b) they share similar fundamental characteristics, or (c) both” (Kristoff, 1996, p. 45). The construct was developed from an interactionist position, and is based on the assumption that human behaviour is a function of both the person and the environment and that there must be compatibility between the two (Terborg, 1981). From this perspective, organisational behaviour results from the ongoing interaction between the employee and the organisation. There are other types of fit than person-organisation fit, including person-job fit, person-team fit and person-career fit (Kristoff, 1996). Person-organisation fit can be understood from the perspective of the attraction-selection-attrition cycle (Schneider, 1987, 2001). According to this model, people are differentially attracted to careers and organisations according to their personality, interests, needs and values. Organisations also tend to select members who are seen as compatible with the needs and values of the organisation. Further, after people enter an organisation, an attrition process occurs whereby employees who do not fit with the organisation tend either to leave it voluntarily or be dismissed from it. Employees who do not fit with an organisation tend to attract less support and assistance from colleagues and may be undermined by them, and they tend to receive less organisational support and sponsorship. Thus, they are less well positioned to contribute to an organisation's productivity, and less well positioned to obtain the objective (e.g., pay, promotion) and subjective rewards (e.g., job satisfaction) that might encourage them to remain with the organisation or encourage the organisation to retain them.

The attraction-selection-attrition cycle is consistent with Holland's (1997) RIASEC theory of career and work, and consistent with Lofquist and Dawis' (1984) theory of work adjustment. Holland (1997) proposed that there were six basic personality types: realistic, investigative, artistic, social, enterprising and conventional. Most people can be allocated to one of these broad personality types, and the same six types can be used to describe work and other environments (e.g., educational environments). People seek out work environments that allow their personality to be expressed, and when engaged in such settings are more satisfied and achieve more. People also change their jobs or are dismissed because 
they experience person-environment incongruence or perceive an opportunity to improve congruence elsewhere. Similarly, work adjustment, according to the work and adjustment theory, is "the process and the outcome of the interaction between an individual and a work environment that results in mutual satisfaction" (Lofquist \& Dawis, 1984; p. 217). Work adjustment results when the employee is satisfied with the organisation, and, in turn, is viewed as satisfactory by the organisation. Job satisfaction is the result of the fit between the employee's needs and what the organisation can offer, whereas organisational satisfaction with the employee (known as satisfactoriness) is the result of how well the employee's skills, ability and attitude meet the needs of the organisation. Job satisfaction is thought to improve satisfactoriness, and satisfactoriness is thought to improve satisfaction. Work adjustment will, on the one hand, increase the likelihood of the employee remaining with the organisation, and, on the other, increase the likelihood of the organisation retaining the employee. A disruption to the work adjustment, or fit between the person and the organisation, will reduce the satisfaction of one or both parties, and could lead to the voluntary or forced exit of the employee from the organisation.

The attraction-selection-attrition cycle processes tend to increase the homogeneity of organisation members, raise the general level of congruence or compatibility between remaining employees and the organisation, and, in turn, account for the widely identified relationship between person-organisation fit and work attitudes, such as job satisfaction, organisational commitment, and turnover intentions (Verquer, Beehr, \& Wagner, 2003), and between person-organisation fit and work performance (Arthur, Bell, Villado, \& Doverspike, 2006). Organisations provide a wide array of opportunities to have personal needs met, that is, to increase the employee's satisfaction, including the opportunity for social contact, skill development and use, status, personal control, variety and structure (Warr, 2007). When there is a strong fit between the person and the organisation, the person has a better opportunity to have these needs met (Schneider, Kristof-Brown, Goldstein, \& Smith, 1997), which results in more favourable attitudes towards the organisation and their work (Arthur et al., 2006).

Fit can also be enhanced by the career management practices employed by the organisation. Research to date in this area has focused primarily on the effect of early socialisation and training activities (Allen, 2006; Cable \& Parsons, 2001). Socialisation occurs before the employee joins the organisation (anticipatory stage), when the employee first enters the organisation (encounter stage) and when the employee adapts and settles into the organisation (adaptation phase; Bauer, Morrison, \& Callister, 1998). Socialisation practices that are implemented at the encounter and adaptation phases can be classified into six broad categories, of formal (e.g., structured training), collective (e.g., training with others), sequential (e.g., overt advice regarding order of training or orientation), fixed (e.g., advice regarding time required for training), serial (e.g., providing mentors) and investing practices (e.g., providing social support; Van Maanen \& Schein, 1979). These career management practices assist adjustment to the job and organisation, improve satisfaction, commitment and productivity, and bring into closer alignment those values related to perceptions of person-organisation fit (Allen, 2006; Ashforth \& Saks, 1996; Cable \& Parsons, 2001). In this way, fit can be seen as a mechanism for career development as well as for career direction, partly driven by the individual him or herself in the selection phase of the cycle, but also driven by the organisation through the strategies it uses to select and maintain employees.

\section{Stages of Organisational Career Development}

Ideally, organisation career management strategies should meet the needs of adults at the various stages of their working life. Career theorists such as Super (Super, Savickas, \& Super, 1996) and Holland (1997) included adult development in their general approaches, and others have specifically identified the phases or stages that adults pass through during their working lives. Schlossberg (1978) has pointed out that these phases, and career development in adults in general, are largely, though not exclusively, driven by social and psychological factors, rather than by biological processes, which is more so the case with children and adolescents. Schein (1971) proposed four stages to the work cycle, of entry, socialisation, mid-career and late-career, and identified specific occupational tasks for the person at each stage. For example, the main task for the person in the mid-career stage is to identify his or her career anchor, or occupational self-concept, which is founded on one's abilities, competencies, values and career related goals. For example, someone with a career anchor of seeking security and/or stability will want to maintain or work in jobs that provide stability and continuity of employment, and may trade off other opportunities and benefits for it. Schein (1990) proposed eight career anchors, which he labelled technical/functional competence, general managerial competence, autonomy/independence, security/stability, entrepreneurial creativity, service/dedication to a cause, pure challenge and lifestyle. Thompson, Baker and Smallwood (1986) linked a four-stage model of careers (Dalton, Thompson, \& Price, 1977) specifically to adult development, indicating not only that performance requirements 
change across the stages (e.g., expectations differ for new entrants and experienced employees) but that standard organisational career development practices are more effective when used within this framework. Key characteristics of the Thompson et al. model are:

Stage 1: employee works under supervision; tasks undertaken are not critical; tasks are more routine; employee lacks status and influence

Stage 2: employee works more independently; given more responsible tasks; has credibility in organisation; increased confidence, ability and influence;

Stage 3: employee has depth and breadth of skills; begins working across areas and outside of organisation; makes significant contributions in organisation; stimulates and mentors others

Stage 4: represents organisation internally and externally; provides direction for organisation; has formal and informal influence; prepares/mentors promising individuals.

This model suggests that new entrants to the workforce would welcome challenging assignments that would allow them to learn new skills, whereas employees at Stage 2 might view variety of work experiences as more important. In the same way, other organisational career management strategies, such as training, mentoring, and appraisal, need to be selectively applied depending on the particular stage of the employee.

\section{Career Success}

Both organisational and self-management career strategies are aimed at optimising the effectiveness of individual careers, that is, optimising career success. Career success is important to individuals as it affects much of the rest of their lives, and it is important for organisations, as how well individuals do is related to organisational success (Judge, Higgins, Thoresen, \& Barrick, 1999). Career success is defined as the positive personal and work-related outcomes that accrue from one's work activities and experiences, and has typically been operationalised as either objective (extrinsic to the person) or subjective success (intrinsic to the person; London \& Stumpf, 1982). Objective career success is related to work performance and measured by indicators such as salary, rate of promotion or level/status achieved. Subjective career success is more closely aligned with personal satisfaction and is reflected in criteria such as job satisfaction, life satisfaction, self-perceptions of status, and beliefs about one's employability. Hall (2002) has suggested a spiral model for success where objective success leads to feelings of subjective success, which, in turn, feeds into work orientated motivation that increases objective success, which again increases subjective success, and so on. In this model, objective success precedes subjective feelings of success.

Turner (1960) identified two systems operating within traditional organisational structures that promoted successful upward mobility: contest mobility, which assumes that promotion and other forms of success are subject to competition among employees; and sponsored mobility, which assumes that success is via patronage from influential/powerful people within the organisation. Contest mobility assumes that achievement is related to effort and the contributions that an employee makes to an organisation, whereas sponsored mobility occurs because influential people within an organisation dispense patronage (Ng, Eby, Sorensen, \& Feldman, 2005). Evidence is stronger for the existence of contest mobility (Judge, Kammeyer-Mueller, \& Bretz, 2004), although both systems are likely to operate to some extent within any organisation and require attention from both the individual and the employer when contemplating the value of career development strategies.

Career success has been associated with a wide range of demographic variables, including age, gender, marital status, cultural background and socio-economic status, which are largely beyond the control of the individual. However, career success also has antecedents such as education and training that can be influenced by both the individual and the organisation using a combination of career selfmanagement strategies and organisational strategies. Ng et al. (2005), in their meta-analysis, classified variables antecedent to career success under four dimensions of human capital (e.g., work experience, education and training, political knowledge), organisational sponsorship (mentoring, organisational support, resources made available by the organisation), socio-demographic status (e.g., gender, race, marital status, age), and stable individual differences (dispositional traits and cognitive ability). These authors argued that human capital variables were more likely to come into play with contest mobility and sponsorship and socio-demographic variables with sponsored mobility. Ng et al. also found that variables from all four dimensions consistently correlated with their outcome variables of salary, promotions and career satisfaction. Evaluations of subjective, rather than objective, success has been argued to be more salient to the new (protean and boundaryless) careers as individuals in these careers are presumed to be driven more by personal goals and values and less by materialistic gain (Hall \& 
Mirvis, 1996; Hall \& Chandler, 2005), although it is also the case that highly skilled workers, those who can best adopt a new career perspective, can have a stronger focus on subjective success as their objective success is more secure (Arnold \& Cohen, 2007). Finally, in terms of career success, women remain disadvantaged relative to men on both objective and, to a lesser extent, subjective criteria, and non-whites do poorer than whites on both (Ng et al., 2005). These outcomes are likely to reflect ongoing community-based social injustice as well as social injustice existing in business organisations (Arnold \& Cohen, 2007).

\section{Theoretical Perspectives}

The organisational-based theories outlined above have drawn primarily from the Western positivist perspective. This perspective assumes that behaviour has regular patterns that can be identified through observation and reason to determine cause-and-effect relationships. These assumptions are also in keeping with assumptions held by many executives, managers and employees within organisations who hold that the social world can be measured and studied in such a way (Collin, 1998). In recent years, however, the focus on careers has become more multi-disciplinary and also included constructivist and social constructionist viewpoints (Arnold \& Cohen, 2007). Arthur, Hall, and Lawrence (1989), for example, argued that many social science disciplines (e.g., psychology, sociology, anthropology, economics, political science and history) have a position on career development within organisations. Taking a multi-disciplinary approach does make sense, as careers "cut across individual, group, organizational and societal levels [and] potentially influence all these levels and, in turn, are influenced by these levels” (Iellatchitch, Mayrhofer, \& Meyer, 2003, p. 729). To date, however, multi-disciplinary perspectives, while contributing to a broader perspective on career development, have also served to work against the development of a coherent and unified approach to understanding the phenomena as, by definition, they are multi-focused, complex and draw on different assumptions, methodologies and even language (Baruch \& Peiperl, 2000). The use of non-positivist approaches to the study of careers in organisations has also grown. These approaches "allow both the contextualisation of career and an understanding of its subjective dimension” (Collin, 1998, p. 416), and include narrative and discourse approaches, metaphors, case studies and life histories (Arnold \& Cohen, 2007).

\section{CAREER DEVELOPMENT AND MANAGEMENT IN TODAY’S ORGANIZATIONS}

The notion of organised, stable career paths that unfold over the lifetime of the person, where both the employee and the organisation contribute to the career and personal development of the individual, has come under challenge in recent decades. This challenge has been brought about by changing economic conditions related to the processes of globalisation, trade deregulation, technological advancements and increases in labour and on-costs (Feldman \& Ng, 2007; Noon \& Blyton, 2002; Storey, 2000). These developments have forced changes to the structure of many workplaces, where restructuring, delayering and downsizing have become the norm, and where traditional workplace patterns are increasingly being replaced by temporary, part-time, portfolio and self-employed work (Platman, 2004; Savickas, 2000). On top of this, not all employees now expect a long-term, traditional career, and many even see these as restricting and undesirable and are not seeking them out (Hall \& Mirvis, 1996). Traditional organisational careers are seen to be in retreat, and being replaced with new career models where the focus is primarily on individual flexibility and adaptability (Baruch \& Peiperl, 2000). These new career models include the boundaryless (Arthur \& Rousseau, 1996) and protean careers (Hall \& Mirvis, 1996).

\section{New Career Models}

The boundaryless career model was proposed largely as a means of describing and understanding the responses and competencies required of individuals facing new organisational structures (Arthur \& Rousseau, 1996). Boundaryless careers are "sequence[s] of job opportunities that go beyond the boundaries of single employment settings” (DeFillipi \& Arthur, 1994, p. 307). They are career paths not restricted by individual organisational boundaries, but rather, are characterised by job mobility, multiple employers, portable competencies suitable for project-based activities, social networks that define and sustain the career, and values that eschew traditional career advancement in favour of personal and/or family goals. Boundaryless careers, unlike traditional careers, are non-linear, multidirectional and non-hierarchical (Lichtenstein \& Mendenhall, 2002). 
The protean career model (Proteus was a Greek God who could change shape at will), on the other hand, has a specific focus on the individual and the psychological components of new careers, and can be viewed as "less instrumental and market orientated than the boundaryless concept" (Arnold \& Cohen, 2007, p.13). Protean-orientated individuals are seen to have personal goals of "learning, psychological success, and expansion of identity" (Hall \& Mirvis, 1996, pp. 35), compared to the traditional organisational goals of promotion, status and power. The psychological contract for the protean career is typically short-term, transactional (rather than relational), and includes, in part, exchanging work in return for opportunities to gain new skills, networking and enhanced marketability (Altman \& Post, 1996). Human and social capital, which are the skills, abilities, effort, time, and networks possessed by the individual and invested when employed (Davenport, 1999), become much more important with the protean career. Individuals who follow this path need to continually upgrade their skills and contacts, as employability, rather than job security within an organisation, is paramount. Security comes with the individual's knowledge that she or he has the personal and social capital to locate, obtain and execute the next employment experience (Jones \& DeFillippi, 1996).

Much research has supported the emergence of the protean career and the attendant psychological and physical changes in the relationships between individuals and organisations. Maguire (2002), for example, conducted a case study in a large Australian banking organisation and found a decrease in the relational components of the psychological contract (i.e., commitment, loyalty) and an increase in transactional (instrumental) components. Other researchers, however, have pointed out that the traditional career is not likely to disappear (Baruch \& Peiperl, 2000; Lips-Wiersma \& Hall, 2007), and still others are critical of the protean construct, especially of its over-reliance on individualism to the exclusion of other values and orientations and its normative development as the most desirable employment relationship (cf. Arnold \& Cohen, 2007). Further, both the boundaryless and protean career models have been criticized as being currently under-developed and limited in their explanatory powers (Arnold \& Cohen, 2007; Lips-Wiersma \& Hall, 2007). Despite this, the reality of modern day organisations is that protean-like careers exist to some extent (Hall, 2002). Handy (1996), for example, suggested that most contemporary organisations contain three types of employees: core, contract and temporary, with the first having characteristics overlapping with more traditional careers, and the latter two more typical of protean-like careers.

While traditional careers have typically disadvantaged women, there is some evidence that proteanlike careers may suit women, as it allows them to mix work with child-rearing and family responsibilities. Such evidence as there is suggests that, in protean careers, women do as well as men on objective measures of success, such as income earned and career advancement (Reitman \& Schneer, 2003). Protean careers may also suit women better than men as they are more likely to set goals around personal growth, rather than around organisational and career achievement, which is more typical for men (Still \& Timms, 1998; Tolbert \& Moen, 1998).

Pressures from the new careers models have fostered a growing uncertainty and job insecurity in the labour market (Garavan, Morley, Gunnigle, \& Collins, 2001). This has meant that individuals must remain focused on their employability within and across organisations. The key elements of employability revolve around the accumulation of competencies related to working in teams, development of networks, the acquisition and application of knowledge, and the cultivation of a portfolio of skills and experiences (Arnold, 1997; Hall, 1996). The ongoing onus on individuals is to realistically and effectively reflect on their career strengths and weaknesses and seek development and/or assistance where and when required. Employability competencies can be enhanced in many ways by using organisational career management strategies initiated by both the individual and the organisation (Garavan et al., 2001). What is important, however, is that the imperatives of employability and marketability impose new prescriptions on the individual, such as actively focusing on their own mobility within their current organisation or movement to another organisation, to avoid the development of situation specific skills that might be less transferable and at risk of becoming obsolete (Bird, 1996).

\section{Career Self-management}

Importantly, for this discussion, each type of employee, whether they are core, contract or temporary, protean or traditional, will have his or her own set of career development needs. A key element to the protean career is that the career is managed largely by the individual rather than the organisation:

The protean career is a process which the person, not the organization, is managing... the protean person's own personal career choices and search for self-fulfilment are the unifying or integrative 
elements in his or her life, [and the] criterion of success is internal (psychological success) not external (Hall, 1976, p.201).

Career self-management implies independence from organisational career management practices and instead includes individually driven processes that involve generating information, plans and strategies to develop and manage one's own career (Sturgess et al., 2002). This is in stark contrast to the traditional approach to career management where the organisation assumed primary responsibility for its employees' development (Thompson et al., 1986). Hall (2002) points out that some employers are prepared to abrogate totally their responsibility for career management and are prepared to view their employees as "free agent[s]" (p. 28), completely accountable for their own career development and management. Other employers take the position that organisational career development and management HRM functions operate to their advantage and to the advantage of their employees and should be retained, especially for core employees.

What then are the goals and strategies for these employers? Hall (2002) argues that the organisation's goals should be to foster employee adaptability and help them develop a clear sense of personal and work identity. Employees need to be adaptable to cope with the instability and continuous change that occurs in today's workplaces, and they need to have a clear sense of identity that can act as an "internal compass" (p. 32) in the midst of this instability and change. Hall proposes that organisations need to adopt a continuous learning perspective, meaning that 'firms will not 'manage' employee's careers, as they did in the past, [rather, they] will provide opportunities and flexibility and resources... to enable the employee to develop identity and adaptability... and be in charge of his or her own career" (p. 36). The strategies to achieve these goals fall under the two broad domains of new work challenges and relationships. New work challenges include strategies of job/task rotations and work restructuring to avoid repetition and stagnation, whereas relationships-based strategies include structuring work activities so that employees learn from their peers, subordinates, supervisors, and even customers and suppliers. Specific relationship strategies include mentoring, work teams and coaching. Needless to say, organisations in these situations must walk a fine line between adopting a traditional organisation career development and management approach and providing resources and opportunities that will foster and sustain career self-management, an important characteristic of the protean perspective.

In a recent study, Lips-Wiersma and Hall (2007) found that in the organisation they studied (a medium size, public organisation in New Zealand with 2400 employees), employees were accepting and positive about the organisation's move for them to take on more of the responsibility for their own career development and management, but also "preferred boundaries, certainty, and security to build their families and lives upon” (p. 788). The organisation, on the other hand, wanted to adopt more of a new career approach, but wanted to retain some responsibility for its employees' career development as "it was in the best interest of the organisation" (p. 788). The organisation reported that its changed HRM approach, while more consistent with the new career approach, was more complex and demanding of the organisation, as it required a consideration of the individual's career aspirations as well as the organisation's strategic goals. Lips-Wiersma and Hall (2007) identified five career development areas where both the employee and the organisation were accepting of some joint responsibility:

- development of capacity and employability in the individual (e.g., the organisation meeting the desire for skill enhancement by creating training or secondment opportunities)

- strategic and structural integration (e.g., the organisation meeting the needs for security by identifying and articulating pathways within the organisation)

-cultural integration (e.g., fostering a culture that allows employees more control and responsibility for career confidence)

- diversity management (e.g., meeting work/non-work balance through flexible working hours)

- communication (e.g., the organisation seeking feedback on what individuals need to manage their careers).

Hall and Mirvis (1996) made the assumption that organisations will want to move away from traditional career relationships with their employees and provided ten rules-of-thumb for organisations wanting to encourage successful protean careers:

1. recognise that the employee owns the career

2. support the employee's own career development efforts

3. play a broker's role and link employees with assignments and other people 
4. provide employees with career information and opportunities for career assessment

5. communicate career development and management expectations to employees

6. focus on employee's work planning rather than career planning

7. promote employee's learning through work tasks and relationships

8. engage employee in decisions regarding career development and management

9. define employee's success by ability to switch tasks/jobs, not by mastery of one

10. develop a mindset of continuous learning in employee and organisation.

Organisational career development and management strategies also need to complement and augment the career development strategies devised by the individual employee. King (2004) has categorised these career self-management strategies under three headings: (a) positioning behaviours, where the focus is on developing networks, skills and experience needed to meet one's career goals, and involves deciding about such things as when to change jobs, what training and education to receive, and how best to develop one's social capital; (b) influencing behaviours, where the aim is to affect the decisions of important others who can restrict or enhance career goals, and includes managing one's own image and self-promotion; and (c) boundary management behaviours, which are about balancing work and non-work demands, and include negotiating with important others outside of work to ensure goals and responsibilities in work and other roles are met.

\section{Broader Influences on Career Development}

Careers occur in a context. While this chapter has given primacy to the organisational context, that is, the context of the institutions of labour exchange, which themselves are influenced by, and embedded in, a dynamic labour market and broader economy, Mayrhofer, Meyer, and Steyrer (2007) remind us that other contextual affordances play an important role in the lifelong career endeavour. Other important influences fall under three broad categories of social background, community/societal context, and international context. Social background variables include one's social origin, social class and educational and work histories that influence, for example, inter- and intra-generational opportunities for occupational mobility. Community and societal contexts that influence individual career decision-making and direction include structural inequalities and advantages associated with gender, ethnicity and demography, whereas international influences are beginning to influence how one works (e.g., virtualisation) and where jobs will be located (e.g., where a cheap labour supply is available). The challenge, then, is not simply to understand and explain career development within an organisational context, but rather to understand and explain it within multiple contexts. In Grandjean's (1981) words, careers occur at the "intersection of societal history and individual biography” (p. 1057).

\section{REFERENCES}

Allen, D. G. (2006). Do organisational socialisation tactics influence newcomer embeddedness and turnover? Journal of Management, 32, 237-256.

Altman, B. W., \& Post, J. E. (1996). Beyond the “social contract”: An analysis of executives’ views at 25 large companies. In D. T. Hall (Ed.), The career is dead - long live the career: A relational approach to careers. San Francisco, CA: Jossey-Bass.

Argyris, C. (1960). Understanding organisational behaviour. Homewood, IL: Dorsey Press.

Arnold, J. (1997). Managing careers into the $21^{\text {st }}$ century. London: Paul Chapman Publishing.

Arnold, J., \& Cohen, L. (2007). The psychology of careers in industrial and organizational settings: A critical but appreciative analysis. International Review of Industrial and Organizational Psychology, 23, 1-44.

Arthur, W., Bell, S. T., Villado, A. J., \& Doverspike, D. (2006). The use of person-organisation fit in employment decision making: An assessment of its criterion-related validity. Journal of Applied Psychology, 91, 786-801.

Arthur, M. B., Hall, D. T., \& Lawrence, B. S. (1989). Generating new directions in career theory: The case for a transdisciplinary approach. In M. M. Arthur, D. T. Hall, \& B. S. Lawrence (Eds.). Handbook of career theory (pp. 7-25). Cambridge, MA: Cambridge University Press.

Arthur, M. B., \& Rousseau, D. M. (Eds.). (1996). The boundaryless career: A new employment principle for a new organizational era. New York: Oxford University Press.

Ashforth, B. E., \& Saks, A. M. (1996). Socialisation tactics: Longitudinal effects on newcomer adjustment. Academy of Management Journal, 39, 149-178.

Bagdadli, S. (2007). Designing career systems. In H. Gunz, \& M. Peiperl (Eds.). Handbook of career studies (pp. 497-501). Los Angeles, CA: Sage.

Baruch, Y. (1996). Career planning and management techniques in use. Career Development International, 1, 40-49.

Baruch, Y. (2002). Career systems in transition: A normative model for organizational career practices. Personnel Review, 32, 231-251.

Baruch, Y. (2004). Transforming careers: From linear to multidirectional career paths - organisational and individual perspectives. Career Development International, 9, 58-73.

Baruch, Y., \& Peiperl, M. (2000). Career management practices: An empirical survey and implications. Human Resource Management, 39, 347-366. 
Bauer, T. N., Morrison, E. W., \& Callister, R. R. (1998). Organisational socialisation : A review and directions for future research. In G. R. Ferris (Ed.). Research in personnel and human resource management (pp. 149-214). Stamford, CT: JAI.

Bernes, K., \& Magnussen, K. (1996). A description of career development services within Canadian organizations. Journal of Counseling and Development, 74, 569-574.

Bocchino, C. C., Hartman, B. W., \& Foley, P. F. (2003). The relationship between person-organization congruence, perceived violations of the psychological contract, and occupational stress symptoms. Consulting Psychology Journal: Practice and Research, 55, 203-214.

Cable, D. M., \& Parsons, C. K. (2001). Socialization tactics and person-organization fit. Personnel Psychology, 54, 1-23.

Collin, A. (1998). New challenges in the study of career. Personnel Review, 27, 412-425.

Dalton, G., Thompson, P., \& Price, R. (1977). Career stages: A model of professional careers in organizations. Organization Dynamics, 6, 19-42.

Davenport, T. O. (1999). Human capital: What it is and why people invest in it. San Francisco, CA: Jossey-Bass.

DeFillipi, R. J., \& Arthur, M. B. (1994). The boundaryless career: A competency-based perspective. Journal of Organizational Behaviour, 15, 307-324.

DeVos, A., Buyens, D., \& Schalk, R. (2003). Psychological contract development during organizational socialization: Adaptation to reality and the role of reciprocity. Journal of Organizational Behavior, 24, 537-559.

Feldman, D. C., \& Ng, T. W. H. (2007). Careers: Mobility, embeddedness, and success. Journal of Management, 33, 350-377.

Fieldman, D. C., \& Ng, T. W. H. (2007). Careers: Mobility, embeddedness and success. Journal of Management, 33, 350-377.

Garavan, T. N., Morley, M., Gunnigle, P., \& Collins, E. (2001). Human capital accumulation: The role of human resource development. Journal of European Industrial Training, 25, 48-68.

Gottfredson, G.D. (2005). Career development in organizations. In W. B. Walsh, \& M. L. Savickas (Eds.). Handbook of vocational psychology: Theory, research and practice (pp. 297-317). Mahwah, NJ: Lawrence Erlbaum.

Grandjean, B. D. (1981). History and career in a bureaucratic labor market. American Journal of Sociology, 86, 1057-1092.

Gratton, L., \& Hope Hailey, V. (1999). The rhetoric and reality of "new careers”. In L. Gratton, V. Hope Hailey, P. Stiles, \& C. Truss. (Eds.). Strategic Human resource management. Oxford: Oxford University Press.

Greenhaus, J. G., Callanan, G. A., \& Godshalk, V. M. (2000). Career management. (3 ${ }^{\text {rd }}$ Ed). New York: The Dryden Press.

Gutteridge, T. G., Leibowitz, Z. B., \& Shore, J. E., (1993). Organizational career development. San Francisco, CA: JosseyBass.

Guzzo, R. A., Noonan, K. A., \& Elron, E. (1994). Expatriate managers and the psychological contract. Journal of Applied Psychology, 79, 617-626.

Hall, D. T. (1976). Careers in organisations. Glenview, IL: Scott, Foresman.

Hall, D. T. (1990). Career development theory in organisations. In D. Brown \& L. Brooks (Eds.). Career choice and development: Applying contemporary theories and practice $\left(2^{\text {nd }}\right.$ Ed., pp. 422-454). San Francisco, CA: Jossey-Bass.

Hall, D. T. (1996). Long live the career. In D. T. Hall \& Associates (Eds.). The career is dead - long live the career: A relational approach to careers (pp. 1-12). San Francisco, CA: Jossey-Bass.

Handy, C. (1996). Beyond certainty. Boston, MA: Harvard Business School Press.

Hall, D. T. (2002). Careers in and out of organizations. Thousand Oaks, CA: Sage.

Hall, D. T. \& Associates. (1986). Career development in organisations. San Francisco, CA: Jossey-Bass.

Hall, D. T., \& Chandler, D. E. (2005). Psychological success: When the career is a calling. Journal of Organisational Behavior, 26, 155-176.

Hall, D. T., \& Mirvis, P. H. (1996). The new protean career: Psychological success and the path with a heart. In D. T. Hall \& Associates (Eds.). The career is dead - long live the career: A relational approach to careers (pp. 15-45). San Francisco, CA: Jossey-Bass.

Handy, C. (1996). Beyond certainty. Boston, MA: Harvard Business School Press.

Hedge, J. W., Borman, W. C., \& Bourne, M. J. (2006). Designing a system for career development and advancement in the U. S. Navy. Human Resource Management Review, 16, 340-355.

Herr, E. L., Cramer, S. H., \& Niles, S. G. (2004). Career guidance and counseling through the lifespan: Systematic approaches. Boston, MA: Pearson.

Herriot, P. (1992). The career management challenge: Balancing individual and organizational needs. London: Sage.

Herriot, P., Manning, W. E. G., Kidd, J. M. (1997). The content of the psychological contract. British Journal of Management, 8, 151-162.

Herriot, P., \& Pemberton, C. (1996). Contracting careers. Human Relations, 49, 757-790.

Holland, J. L. (1997). Making vocational choices: A theory of vocational personalities and work environments. Odessa, FL: Psychological Assessment Resources.

Iellatchitch, A., Mayrhofer, W., \& Meyer, M. (2003). Career fields: A small step towards a grand theory? International Journal of Human Resource Management, 14, 728-750.

Judge, T. A., Higgins, C. A., Thoresen, C. J., \& Barrick, M. R. (1999). The Big Five personality traits, general mental ability, and career success across the lifespan. Personnel Psychology, 52, 621-651.

Judge, T. A., Kammeyer-Mueller, J., \& Bretz, R. D. (2004). A longitudinal model of sponsorship and career success: A study of industrial-organisational psychologists. Personnel Psychology, 57, 271-303.

King, Z. (2004). Career self-management: Its nature, causes and consequences. Journal of Vocational Behavior, 65, 112-133.

Kristof, A. L. (1996). Person-organisation fit: An integrative review of its conceptualization, measurement, and implications. Personnel Psychology, 49, 1-49.

Leibowitz, Z. B., Farren, C., \& Kaye, B. L. (1986). Designing career development systems. San Francisco, CA: Jossey-Bass Publishers.

Levinson, H., Price, C. R., Munden, K. J., Mandl, H. J., \& Solley, C. M. (1962). Men, management and mental health Cambridge, MA: Harvard University Press.

Lichtenstein, B. M. B., \& Mendenhall, M. (2002). Non-linearity and response ability: Emergent order in $21^{\text {st }}$ century careers. Human Relations, 55, 5-31.

Lips-Wiersma, M., \& Hall, D. T. (2007). Organizational career development is not dead: A case study on managing the new career during organizational change. Journal of Organizational Behavior, 28, 771-792.

London, M. (2002). Organizational assistance in career development. In D.C. Feldman, Work careers: A developmental perspective (pp.323-345). San Francisco, CA: Jossey-Bass.

London, M. \& Stumpf, S. A. (1982). Managing careers. Reading, MA: Addison-Wesley.

Maguire, H. (2002). Psychological contracts: are they still relevant? Career Development International, 7, 167-180. 
Mayrhofer, W., Meyer, M., \& Steyrer, J. (2007). Contextual issues in the study of careers. In H. Gunz, \& M. Peiperl (Eds.). Handbook of career studies (pp. 215-240). Los Angeles, CA: Sage.

McClelland, S. (1994). Gaining competitive advantage through strategic management development. Journal of Management Development, 13, 4-13.

McDaniels, C., \& Gysbers, N. C. (1992). Counselling for career development ( $1^{\text {st }}$ Ed.). Can Francisco, CA: Jossey-Bass Publishers.

Morrisson, R. F., \& Hock, R. R. (1986). Career building: Learning from cumulative work experience. In D. T. Hall (Ed.). Career development in organizations (pp. 236-273). San Francisco, CA: Jossey-Bass.

National Training Information Service. (2008). What is a competency? Retrieved from http://www.ntis.gov.au/.

Ng, T. W. H., Eby, L. T., Sorensen, K. L., \& Feldman, D. C. (2005). Predictors of objective and subjective career success: A meta-analysis. Personnel Psychology, 58, 367-408.

Noon, M., \& Blyton, P. (2002). The realities of work. London: Palgrave.

Olson, L. (1997). The school to work revolution. How employers and educators are joining forces to prepare tomorrow's skilled workforce. Reading, MA: Addisen-Wesley.

Platman, K. (2004). "Portfolio careers" and the search for flexibility in later life. Work, Employment and Society, 18, 573-600.

Puah, P., \& Ananthram, S. (2006). Exploring the antecedents and outcomes of career development initiatives: Empirical evidence from Singaporean employees. Research and Practice in Human Resource Management, 14, 112-142.

Reitman, F., \& Schneer, J. A. (2003). The promised path: A longitudinal study of managerial careers. Journal of Managerial Psychology, 18, 60-75.

Robinson, S. L. (1996). Trust and breach of the psychological contract. Administrative Science Quarterly, 41, 574-599.

Robinson, S. L., \& Rousseau, D. M. (1994). Violating the psychological contract: Not the exception but the norm. Journal of Organizational Behaviour, 11, 389-400.

Rousseau, D. M. (1990). New hire perceptions of their own and their employer's obligations: A study of psychological contracts. Journal of Organizational Behaviour, 11, 389-400.

Rousseau, D. M. (1995). Psychological contracts in organizations: Understanding written and unwritten Agreements. London: Sage.

Savickas, M. (2000). Renovating the psychology of careers for the twenty-first century. In A. Collin \& R. A. Young (Eds.). The future of career. Cambridge, MA: Cambridge University Press.

Schein, E. H. (1971). The individual, the organization, and the career: A conceptual scheme. Journal of Applied Behavioral Science, 7, 415-416, 421-424.

Schein, E. H. (1990). Career anchors: Discovering your real values. San Francisco, CA: Jossey-Bass.

Schlossberg, N. K. (1978). Five propositions about adult development. Journal of College Student Personnel, 19, 418-423.

Schneider, B. (1987). The people make the place. Personnel Psychology, 40, 437-453.

Schneider, B. (2001). Fits about fit. International Review of Applied Psychology, 50, 141-152.

Schneider, B., Kristof-Brown, A., Goldstein, H. W., Smith, D. B. (1997). What is this thing called fit? In N. Anderson, \& P. Herriot (Eds.), International Handbook of Selection and Assessment (pp. 393-412). Chichester: John Wiley and Sons.

Sonnenfeld, J. A., \& Peiperl, M. A. (1988). Staffing policy as a strategic response: A typology of career systems. Academy of Management Review, 13, 588-600.

Still, L. \& Timms, W. (1998). Career barriers and the older woman manager. Women in Management Review, 13, 143-156.

Storey, J. (2000). "Fractured lines" in the career environment. In A. Collin \& R.A. Young (Eds.). The future of career. Cambridge, MA: Cambridge University Press.

Sturges, J., Conway, N., Guest, D., \& Liefooghe, A. (2005). Managing the career deal: The psychological contract as a framework for understanding career management, organizational commitment and work behaviour. Journal of Organizational Behavior, 26, 821-838.

Sturgess, J., Guest, D., Conway, N., \& Mackenzie Davey, K. (2002). A longitudinal study of the relationship between career management and organisational commitment among graduates in the first ten years at work. Journal of Organizational Behavior, 23, 731-748.

Super, D. E., Savickas, M. L., \& Super, C. M. (1996). The life-span, life-space approach to careers. In D. Brown, L. Brooks et al. (Eds.). Career choices and development ( $3^{\text {rd }}$ Ed., pp. 121-178. San Francisco, CA: Jossey-Bass.

Suutari, V. (2002). Global leader development: An emerging research agenda. Career Development International, 7, 218-233.

Tekleab, A. G., Takeuchi, R., \& Taylor, M. S. (2005). Extending the chain of relationships among organizational justice, social exchange, and employee reactions: The role of contract violations. Academy of Management Journal, 48, 146-157.

Terborg, J. R. (1981). Interactional psychology and research on human behavior in organizations. Academy of Management Review, 6, 569-576.

Thompson, P. H., Baker, R. Z., \& Smallwood, N. (1986). Improving professional development by applying the four-stage career model. Organizational Dynamics, 15, 49-62.

Tolberrt, P. S., \& Moen, P. (1998). Men's and women's definitions of "good” jobs: Similarities and differences by age and across time. Work and Occupations, 25, 168-194.

Turner, R. J. (1960). Sponsored and contest mobility and the school system. American Sociological Review, 25, 855-867.

Turnley, W. H., Bolino, M. C., Lester, S. W., \& Bloodgood, J. M. (2003). The impact of psychological contract fulfillment on the performance of in-role and organizational citizenship behaviors. Journal of Management, 29, 187-212.

Turnley, W. H., \& Feldman, D. C. (1999). The impact of psychological contract violations on exit, voice, loyalty, and neglect. Human Relations, 52, 895-922.

Van Maanen, J., \& Schein, E. H. (1979). Towards a theory of organisational socialisation. In B. M. Staw (Ed.). Research in organisational behavior (pp. 209-264). Greenwich, CT: JAI.

Verquer, M. L., Beehr, T. A., \& Wagner, S. H. (2003). A meta-analysis of relations between person-organization fit and work attitudes. Journal of Vocational Behavior, 63, 473-489.

Warr, P. (2007). Work, happiness, and unhappiness. Mahwah, NJ: Lawrence Erlbaum Associates.

Winterton, J. \& Winterton, R. (1999). Developing managerial competence. London: Routledge.

Yeatts, D. L., Folts, W. E., \& Knapp, J. (2000). Older workers’ adaptation to a changing workplace: Employment issue for the $21^{\text {st }}$ century. Educational Gerontology, 26, 565-582. 
Peter Creed

School of Psychology

Griffith University

Australia

Michelle Hood

School of Psychology

Griffith University

Australia

Brief Bio - Peter Creed

Peter Creed is Professor of Organisational Psychology in the School of Psychology, Griffith University, Australia. Before this he worked for the Australian government employment service. His research interests include school-to-work transition, career development, adolescent and adult unemployment, and occupational wellbeing. His teaching responsibilities entail organisational and career psychology and psychometrics.

Brief Bio - Michelle Hood

Michelle Hood is a lecturer in the School of Psychology, Griffith University, Australia. Her research interests include career development, academic motivation and achievement, and literacy and numeracy development. Her teaching responsibilities entail lifespan developmental psychology and research methods and statistics. 